36. Tsiganenko, L. F. (2009). Dvoryanstvo Pivdnya Ukraini (druga polovina XVIII st. - 1917 r.) [Nobility of the Great Ukraine (the second half of the XVIII century - 1917)] : Monografiya. Izmail: SMIL.

37. Shtat Bessarabskoy oblasti po vnutrennemu upravleniyu ( 29 aprelya $1818 \mathrm{~g}$. ot № 27357) (1830). Polnoe sobranie zakonov Rossiyskoy imperii [Staff of the Bessarabian Region for internal management (April 29, 1818 from No. 27357). Complete collection of laws of the Russian Empire]. Spb.: Tipografiya II Otdeleniya Sobstvennoy EIV Kantselyarii, Tom XLIV. Chast 2. Kniga shtatov. Otdelenie III i IV. S. 22.

38. Tomulet, V. (2013). Din istoria fondării şi activităţii biroului regional (gubernial) de hotărnicie din Basarabia (1818-1890) [From the history of the foundation and activity of the Bessarabian Regional (gubernial) Bureau of authority (1818-1890)]. Revistă Ştiinţifică a Universităţii de Stat din Moldova.

УДК 930(477) «18/19»

\title{
УЧИТЕЛЬСЬКІ ІНСТИТУТИ В СИСТЕМІ ПЕДАГОГІЧНОЇ ОСВІТИ НАДДНІПРЯНСЬКОЇ УКРАЇНИ ДРУГОЇ ПОЛОВИНИ ХІХ - ПОЧАТКУ ХХ СТ.: АНАЛІЗ СУЧАСНОЇ ІСТОРІОГРАФІЇ
}

\section{Ломако Людмила}

У статті проаналізовано праці дослідників сучасного періоду, присвячені становленню і розвитку вчительських інститутів в украӥнських землях другої половини XIX - початку XX cm. Показано інформаційний потенціал досліджень, види, тематику видань, оиінено внесок сучасних авторів у вивчення проблеми. Використано такі методи дослідження як систематизаиія наукової літератури, операціоналізація понять, хронологічно-системний $і$ проблемно-почуковий, структурно-порівняльний аналіз джерел. Дослідження базується на принципах науковості, системності, історизму, об'єктивності, єдності історичного і логічного, теорії і практики. Аналіз сучасних досліджень засвідчив наявність трунтовного досвіду професійно-педагогічної підготовки в учительських інститутах Наддніпрянської України другої половини XIX - початку XX сm. Авторами колективних праць $i$ монографій, загальних $i$ регіональних видань зібрано багатий фактологічний матеріал, залучено нові джерела. 3 'являються спроби ијілісно відобразити історію створення, стан та діяльність окремих учительських інститутів, їхнє місие $i$ роль у системі педагогічної освіти Украйни зазначеного періоду, визначити зміст, провідні тендениії $і$ особливості їх адміністративно-організаційного устрою. Результати роботи можуть бути використані під час проведення досліджень з історіографіï, історії 
України другої половини XIX - початку XX cm., історії педагогіки, у процесі розробки спецкурсів з історії освіти України. Перспективи вивчення проблеми пов'язуємо з розширенням кола наукових видань, дослідженням періодичної преси.

Ключові слова: учительські інститути, педагогічна освіта, сучасна історіографія.

Сучасне реформування української школи вимагає від вчителів та вчених не тільки теоретичного усвідомлення нових тенденцій у педагогічній науці, творчого розв'язання потреб шкільної практики, але і потребує більш грунтовного вивчення, переосмислення та використання досвіду, накопиченого провідними фахівцями і освітніми установами минулого. Найбільше цікавлять періоди, пов'язані $з$ появою нових концепцій, підходів, становленням нових навчальних закладів. В історії української педагогічної освіти це друга половина XIX - початок XX ст. - час духовно-культурного відродження українства, активного реформування освітньої галузі. Інтенсивно відбуваються становлення та трансформація змісту, форм, моделей педагогічної освіти, що зумовлюють появу нових, реорганізацію, перепрофілювання існуючих педагогічних навчальних закладів відповідно до вимог часу. Чільне місце серед них належить учительським інститутам, перші 3 яких було відкрито 1874 р. у Глухові та Феодосії. Згідно Статуту учительських інститутів, розробленого Міністерством народної освіти ще 1862 р., ці середні спеціальні навчальні заклади здійснювали теоретичну, методичну і практичну підготовку вчительських кадрів для початкової школи підвищеного типу. Вже дослідження тогочасної доби свідчать, що провідними викладачами інститутів розроблено поглиблені наукові програми і відповідні їм навчальні курси з історії педагогіки, дидактики, теорії виховання, окремих методик, накопичено досвід практичної підготовки, закладено основи наукових досліджень щодо особистості дитини, інтеграції змісту педагогічних дисциплін тощо. 3 огляду на це, вивчення досвіду учительських інститутів під кутом новітньої методології $\epsilon$ актуальним як у науковопізнавальному, так і практичному сенсі.

Доробок історіографії другої половини XIX - початку XX ст. щодо вивчення діяльності вчительських інститутів досить суттєвий. Статутні правила, накази, розпорядження, інструкції, що регламентували діяльність навчальних закладів знаходимо в збірниках постанов i розпоряджень по Міністерству народної освіти, історичному огляді його діяльності та матеріалах для історії освітніх реформ XVII - XIX ст. (С. В. Рождественський). Виходили друком профільні збірники постанов і розпоряджень, правил i інструкцій, думок i зауважень щодо педагогічних навчальних закладів i, зокрема, вчительських інститутів (Ф. Д. Студитський, Г. А. Фальборк, В. І. Чарнолуський), матеріали з'їздів 3 питань народної освіти, з'їздів директорів учительських інститутів, зібрання навчальних 
планів і програм окремих інститутів (К. М. Щербина), загальні (Н. І. Воротинцев, П. К. Шмулевич) та профільні (Д. С. Марголін) довідники для абітурієнтів. Організацію навчального процесу, діяльність професорськовикладацького складу висвітлювали загальні дослідження стану тогочасної освіти (А. Н. Куломзін, А. Л. Меленєвський, Г. А. Фальброк, В. І. Чарнолуський), історичні нариси окремих інститутів (М. І. Ленц). Публікації в періодичних виданнях того часу подають характеристику навчальновиховного процесу в учительських інститутах, піднімають питання їх реформування, поліпшення професійно-педагогічної підготовки вчителя (І. Губкін, П. О. Клунний, І. Клюжев, І. Максимов та ін.). У радянській історіографії у відповідності до тогочасної методології обгрунтовувались теоретичні засади функціонування вчительських інститутів (А. М. Алексюк, О. Г. Мороз), вивчалися окремі аспекти їх розвитку в контексті дослідження становлення системи освіти другої половини XIX - початку XX ст. (М. О. Авдієнко, В. Й. Борисенко, Е. Д. Днєпров, Ф. Г. Паначін, В. З. Смірнов), історії професійно-педагогічної підготовки вчителя (С. Ф. Сгоров, О. Ф. Іванов, Н. А. Філіппова), історії інтелігенції (В. Р. Лейкіна-Свирська). Вирізняються праці, де аналізуються причини, процес виникнення, етапи реформування учительських інститутів, висвітлюються питання організації та змісту навчально-виховного процесу, навчальні плани та програми досліджуваного періоду, недоліки в педагогічній підготовці випускників (М. М. Кузьмін, М. І. Левченко). У сучасний період з'являються спроби охарактеризувати цілісний процес виникнення та розвитку учительських інститутів у системі підготовки педагогічних кадрів в Україні другої половини XIX - початку XX ст., дослідити історію окремих інститутів, що підкреслює актуальність даної розвідки.

3 огляду на вищесказане, метою нашої статті $є$ аналіз праць сучасних дослідників щодо історії створення, стану та діяльності вчительських інститутів в українських землях другої половини XIX - початку XX ст. Для досягнення цієї мети необхідно дослідити історіографічні джерела, які представлені монографіями, брошурами, довідниками, навчальними посібниками, дисертаційними дослідженнями, авторефератами, статтями в періодичних виданнях на зазначену тематику.

Розширення джерельної бази, зміни в теоретико-методологічних підходах до історичних досліджень в пострадянський період обумовили появу низки колективних і індивідуальних праць, що досліджували процес становлення і розвитку педагогічної освіти в українських землях як системної цілісності, пізнання іiі сутності, провідних тенденцій, загальних закономірностей та особливостей професійно-педагогічної підготовки студентів педагогічних навчальних закладів. Конкретно історичні та теоретичні аспекти становлення та розвитку вчительських інститутів в українських землях другої половини XIX - початку XX ст. розкрито в таких загальних дослідженнях, як «Розвиток народної освіти і педагогічної думки на 
Україні (X - початок XX ст.) за редакцією М. Д. Ярмаченка [33], «Історія освіти і науки України» О. Я. Пилипчука, О. Ф. Коновця, Л. П. Яресько [30], «Україна: освіта і держава» Ю. М. Алєксєєва [1], «Українська історіографія історії педагогіки» Н. М. Гупана [6]. Основні методи і форми навчання в учительських інститутах досліджуваного періоду представлено в навчальних посібниках з історії педагогіки Д. І. Латишиної [24], О. І. Піскунова [13]. Основні тенденції й особливості розвитку, зміст, форми та методи навчання і виховання, матеріально-технічне забезпечення вчительських інститутів розкрито у праці Р. С. Гавриш та В. С. Лобурця «Підготовка вчительських кадрів в Україні дорадянської доби» [4].

Спробою цілісно відобразити розвиток учительських інститутів України другої половини XIX - початку XX ст. $є$ дослідження I. М. Кравченко «Учительські інститути в системі підготовки педагогічних кадрів в Україні (друга половина XIX - початок XX ст.)» [20]. Автором виявлено організаційно-педагогічні передумови становлення вчительських інститутів у системі підготовки педагогічних кадрів України другої половини XIX початку XX ст.; обгрунтовано процес становлення і розвитку вчительських інститутів, як поступову, закономірну зміну їх адміністративноорганізаційного устрою, змісту підготовки вчителя, в тому числі професійнопедагогічної, зумовлену суспільно-політичними, соціально-економічними та організаційно-педагогічними перетвореннями цього періоду; розроблено періодизацію даного процесу; виявлено провідні тенденції та особливості розвитку організаційного устрою вчительських інститутів (1874-1904 pp. навчальні заклади інтернатного типу з правом вступу осіб чоловічої статі, 1905-1916 pp. - безінтернатний тип; 1917-1920 pp. - відкриття жіночих та змішаного за контингентом типу вчительських інститутів, відкриття трьох відділень за відповідними спеціалізаціями). Адміністративний устрій упродовж досліджуваного періоду залишався незмінним, учительські інститути функціонували як центри навчально-виховних комплексів. Серед провідних тенденцій та особливостей розвитку змісту професійно-педагогічної підготовки дослідниця виділяе нівелювання загальноосвітньої складової та орієнтацію на поглиблену методичну підготовку (1874-1904рp.); інтеграцію знань у змісті навчальної дисципліни «Педагогіка», розроблення авторських навчальних програм, посилення уваги до вивчення особистості дитини i аномалій iї розвитку, поглиблення практичної підготовки (1905-1916рр.); професіоналізацію, українізацію змісту навчання, диференціацію інтегрованих навчальних дисциплін (1917-1920 pр.). Особливу увагу I. М. Кравченко приділяє професійно-педагогічній підготовці в учительських інститутах України другої половини XIX - початку XX ст. [19]. Окремі праці автор присвятила навчально-виховній діяльності в Київському [18] та Феодосійському вчительських інститутах $[21 ; 22]$.

Історію окремих учительських інститутів висвітлюють й інші автори. Довідниково-прикладний характер має дослідження В. І. Бєлашова, 
М. П. Гурця, В. В. Заїки «Глухівський державний педагогічний інститут (1874-1994 pp.) [2]. Авторами представлено загальну характеристику становлення та розвитку, організації навчально-виховного процесу Глухівського вчительського інституту. Привертає увагу аналіз діяльності директорів та викладачів інституту, їх науково-теоретичних розробок, внеску вихованців та випускників закладу в розвиток навчально-виховного процесу.

Педагогічну спадщину Глухівського вчительського інституту, а саме ідеї педагогічної майстерності в педагогічній діяльності та теоретичних працях викладачів Глухівського вчительського інституту в 1874-1917 pр. висвітлює Л. В. Задорожна $[10 ; 11]$. Автор дослідила концептуальні засади ідей педагогічної майстерності викладачів Глухівського вчительського інституту періоду 1874-1917 років, проаналізувала ідеї змісту, напрямів та умов оволодіння педагогічною майстерністю в теоретичних працях викладачів Глухівського вчительського інституту І. С. Андрієвського, В.В.Голубєва, М. С. Григоревського, М. І. Демкова, С. О. Криловського, А. П. Лєбєдєва, В. О. Сельонкіна, М. А. Тростнікова, вивчила специфіку, форми і методи роботи викладачів інституту по формуванню основ професійної майстерності майбутніх учителів. Л.В.Задорожна доводить, що педагогічні ідеї викладачів інституту лягли в основу їх професійної діяльності, а формування педагогічної майстерності майбутніх викладачів здійснювалося у створеній викладачами інституту оптимальній атмосфері, що гармонійно поєднувала в собі високу вимогливість та суворий контроль за діяльністю студентів 3 глибокою повагою до особистості кожного вихованця, гуманістичні засади спілкування студентів та викладачів, їх спільну творчу діяльність. Значна увага приділялась формуванню практичних дидактичних та виховних умінь та навичок.

Не можливо залишити поза увагою статтю «До історії Житомирського єврейського вчительського інституту (1873-1885 рр.) Н. В. Рудницької, що розкриває особливості підготовки вчителів для викладання в школах, де навчались представники національних меншин [35].

Вагоме значення для дослідження теми має монографія Н. М. Дем'яненко «Загальнопедагогічна підготовка вчителя в Україні (XIX - перша третина XX ст.) [8] та її сумісна праця з I. П. Важинським «Ретроспектива педагогічної освіти в Україні (XIX - початок XX ст.) [7], де висвітлюється діяльність учительських інститутів. На прикладі Глухівського інституту аналізується зміст загальнопедагогічної підготовки, наводиться навчальний план. Автори доводять, що загальнопедагогічна підготовка займала центральне місце в навчально-виховному процесі вчительських інститутів, вирізняючись у кожному з них за змістом, наповненістю і розподілом за роками навчання. 3-поміж основних компонентів загальнопедагогічної підготовки, розроблених на інтегрованій основі, виділяються курси психології, педагогіки, логіки, дидактики, історії педагогічних учень, а також педагогічна практика, що передбачала спостереження й обговорення показових уроків досвідчених 
учителів та проведення практикантами самостійних уроків 3 їх наступним аналізом.

Привертає увагу дослідження О. М. Лук'янченко «Організація педагогічної практики в різних типах педагогічних навчальних закладів України (друга половина XIX - початок XX ст.)» [26], де розкриваються мета, завдання, види, зміст педпрактики, виявляються специфіка, форми і методи іiі проведення, визначаються провідні тенденції організації педагогічної практики та етапи іiі розвитку в досліджуваний період. Зокрема, в роботі частково аналізуються нормативні документи, що регулювали діяльність учительських інститутів, організація та зміст педагогічної практики в Київському i Глухівському інститутах.

Розвиток середньої спеціальної освіти в Україні у другій половині XIX ст. подає $€$. М. Луценко [27]. Щодо запропонованої проблеми необхідно врахувати i результати досліджень В. К. Майбороди «Вища педагогічна освіта в Україні: історія, досвід, уроки (1917-1985 pp.) [28] та М. К. Козія «Розвиток середньої педагогічної освіти в Україні (1945-1900рp.) [16]. В.К. Майборода дає стислу історичну довідку про деякі вчительські інститути, розкриває зміст навчальних планів, описує їх організаційний устрій. М. К. Козій висвітлює процес створення мережі педагогічних училищ саме як правонаступників учительських інститутів.

Історія створення і розвитку вчительських інститутів досліджується в контексті освітньої проблематики кінця XIX - початку XX ст. Так, підготовку студентів до науково-дослідної та методичної роботи в учительських інститутах висвітлює С. Т. Золотухіна [12], досліджуючи засоби навчальної та науково-дослідної роботи; підготовку до впровадження інноваційної діяльності - О. В. Попова [32] в межах проблеми розвитку інноваційних процесів у середніх загальноосвітніх навчально-виховних закладах України в $\mathrm{XX} \mathrm{cт.} \mathrm{Долучаються} \mathrm{до} \mathrm{проблеми} \mathrm{I.} \mathrm{М.} \mathrm{Сучков} \mathrm{[37],} \mathrm{досліджуючи} \mathrm{вчитель-}$ ство кінця XIX - початку XX ст., У. Т. Кіреева [15], Л. О. Хомич [38] професійно-педагогічну підготовку вчителя початкової школи другої половини XIX - початку XX ст., В. О. Вихрущ [3] - розвиток теоретикоконцептуальних основ вітчизняної дидактики (друга половина XIX - початок XX ст., О. І. Пометун [31] - навчання дітей вітчизняної історії в українській початковій школі кінця XIX - початку XX ст.

Оцінки щодо діяльності вчительських інститутів, а саме викладацького складу, їх випускників знаходимо в історико-соціальному нарисі Н. А. Шипа «Інтелігенція на Україні (XX ст.)» [39] та монографії Г.В.Касьянова «Українська інтелігенція на рубежі XIX - початку XX ст.: соціально-політичний портрет» [14]. Проблеми, соціальний склад, матеріальний стан студентів цих закладів аналізує Н. М. Левицька [25], вивчаючи історію студентства України на зламі XIX-XX ст.

Освітня діяльність, а саме відкриття шкіл, підготовка педагогічних кадрів, була основним напрямом діяльності земств досліджуваного періоду. 
Окремі аспекти діяльності вчительських інститутів висвітлено в праці В. В. Курченко «Діяльність земств України в розвитку освіти (1864-1914 рр.) [23] та Р. Л. Гавриш «Шкільна діяльність земського самоврядування на Лівобережній Україні в 1865-1919 рр.» [5]. Загальні питання змісту підготовки в учительських інститутах розкрито в дослідженнях щодо освітньої діяльності земств окремих регіонів. Л. В. Корж [17] вивчала освітню діяльність земств Харківської губернії в кінці XIX - початку XX ст., а Л. Т. Рябовол [36] - розвиток земської освіти в Херсонській губернії другої половини XIX - початку XX ст.

Особливості підготовки, прогресивні тенденції поєднання вивчення змісту шкільних навчальних дисциплін з методами їх викладання в учительських інститутах висвітлюють й інші дослідження з історії розвитку освіти та педагогічної думки в окремих регіонах України. Авторські колективи на чолі з В. І. Свдокімовим [9] та І. Ф. Прокопенком [34] висвітлюють ці процеси на Харківщині, а Ю. А. Надольська - на Півдні України в другій половині ХІХ на початку ХХ ст. [29].

Аналіз сучасних досліджень засвідчив актуальність питання розвитку i модернізації професійно-педагогічної підготовки вчителя та наявність грунтовного досвіду їі реалізації в учительських інститутах України другої половини XIX - початку XX ст. Автори колективних і одноосібних, загальних i регіональних досліджень, праць, що присвячені окремим галузям освіти, зібрали суттєвий фактичний i аналітичний матеріал, виокремили недоліки, запропонували шляхи використання досвіду вчительських інститутів у сучасних умовах. Але виявлено лише одне цілісне дослідження, де визначаються організаційно-педагогічні передумови становлення вчительських інститутів України зазначеного періоду, з'ясовуються їх місце і роль у системі педагогічної освіти, вивчаються зміст, провідні тенденції і особливості їхнього адміністративно-організаційного устрою, професійнопедагогічної підготовки, виявляються провідні ідеї діяльності учительських інститутів (І. М. Кравченко). Позитивно оцінюючи праці сучасних науковців, зазначимо, що поза увагою залишилось ще чимало питань, які потребують глибшого опрацювання джерельної бази. Перспективи вивчення проблеми пов’язуємо з розширенням кола наукових видань, дослідженням періодичної преси.

\section{Abstract}

In the article the works of modern researchers devoted to the formation and development of teachers' institutes in the Ukrainian lands of the second half of the XIX - beginning of the XX century are analyzed. Information potential of researches, kinds, subjects of publications is shown, the contribution of modern authors in studying of a problem is appreciated. Such methods of research as systematization of scientific literature, operationalization of concepts, chronological-system and problem-searching, structurally-comparative analysis of 
sources are used. The research is based on the principles of scientific, systemic, historicism, objectivity, the unity of historical and logical, theory and practice. Analysis of modern research has shown the existence of a significant experience of professional and pedagogical training in the teaching institutes of the Nadneprianska Ukraine of the second half of the XIX - early XX century. The authors of collective works and monographs, generalizing and regional publications have collected rich factual material, new sources have been attracted. There are attempts to holistically reflect the history of the creation, the state and activities of individual teachers' institutions, their place and role in the system of pedagogical education in Ukraine of the period, determine the content, main trends and peculiarities of their administrative and organizational structure. The results of the work can be used to create research on historiography, the history of Ukraine in the second half of the XIX - early XX century, the history of pedagogy, the development of special courses on the history of education of Ukraine. Prospects for studying the problem are associated with the expansion of the range of scientific publications, the study of the periodical press.

Key words: Teaching institutes, pedagogical education, modern historiography.

\section{Аннотация}

В статье проанализированы труды исследователей современного периода, посвященные становлению и развитию учительских институтов в украинских землях второй половинь ХІХ - начала ХХ в. Показан информаичонный потенциал исследований, виды, тематика изданий, оценён вклад современных авторов в изучение проблемы. Использованы такие методы исследования как систематизаџия научной литературы, операџионализация понятий, хронологически-системный и проблемно-поисковый, структурносравнительный анализ источников. Исследование базируется на принципах научности, системности, историзма, объективности, единства исторического и логического, теории и практики. Анализ современных исследований показал наличие существенного опыта профессионально-педагогической подготовки в учительских институтах Надднепрянской Украины второй половины XIX - начала XX в. Авторами коллективных работ и монографий, обобщаюших и региональных изданий собран богатый фактологический материал, привлечены новые источники. Появляются попытки целостно отразить историю создания, состояние и деятельность отдельных учительских институтов, их место и роль в системе педагогического образования Украинь указанного периода, определить содержание, основные тенденции и особенности их административно-организационного устройства. Результаты работь могут быть использованы при создании исследований по историографии, истории Украины второй половины XIXначала ХХв., истории педагогики, разработке спеикурсов по истории 
образования Украины. Перспективы изучения проблемы связываем с расширением круга научных изданий, исследованием периодической печати.

Ключевые слова: учительские институты; педагогическое образование, современная историография.

\section{ДЖЕРЕЛА ТА ЛІТЕРАТУРА}

1. Алєксєєв Ю. М. Україна: освіта і держава (1987-1997). Київ : Експресоб'ява, 1998. 110 с.

2. Бєлашов В. І., Гурець М. П., Заіка В. В. Глухівський державний педагогічний інститут (1874-1994 рр.). Суми : Мрія, 1994. 79 с.

3. Вихрущ В. О. Розвиток теоретико-концептуальних основ вітчизняної дидактики (друга половина XIX - початок XX ст.) : Автореф. дис. ... д-ра пед. наук: 13.00.01 / Нац. пед. ун-т. Київ, 2001. 38 с.

4. Гавриш Р. Л., Лобурець В. С. Підготовка вчительських кадрів в Україні дорадянської доби. Наукові записки психол.-пед. ф-ту Полтавського педінституту. Полтава, 1997. Ч. 1. С. 47-52.

5. Гавриш Р. Л. Шкільна діяльність земського самоврядування на Лівобережній Україні в 1865-1919 рр. : Дис. ... канд. іст. наук: 07.00.01 / Полтавський педінститут. Полтава, 1998. 196 с.

6. Гупан Н. М. Українська історіографія історії педагогіки. Київ : «А. П. Н.», 2002. $224 \mathrm{c}$.

7. Дем'яненко Н. М., Важинський І. П. Ретроспектива педагогічної освіти в Україні (XIX - початок XX ст.). Москва : МПА, 2002. 240 с.

8. Дем'яненко Н. М. Загальнопедагогічна підготовка вчителя в Україні (XIX - перша третина XX ст.). Київ : ІЗМН, 1998. 328 с.

9. Свдокімов В. І., Єльнікова Г. В., Корнілов В. В. Розвиток народної освіти і педагогічної думки на Харківщині. Харків : ХДПІ, 1992. 334 с.

10. Задорожна Л. В. Ідеї педагогічної майстерності в діяльності Глухівського вчительського інституту (1874-1917 рр.) : Дис. ... канд. пед. наук: 13.00.01 / Луганський державний педуніверситет ім. Т. Шевченка. Луганськ, 2000. 187 с.

11. Задорожна Л. В. Педагогічні здобутки викладачів Глухівського учительського інституту дореволюційного періоду 1874-1917 pp. Навчальний посібник. Глухів : РВВ ГДПІ, 1999. 84 с.

12. Золотухіна С. Т. Підготовка майбутніх учителів до науково-дослідної та методичної роботи. Засоби навчальної та науково-методичної роботи. Вип. 2. Харків, 1997. С. 38-42.

13. История педагогики и образования. Уч. пособ. для пед. учеб. звед. / Под ред. А. И. Пискунова. Москва : Сфера, 2001. 512 с.

14. Касьянов Г. В. Українська інтелігенція на рубежі XIX - XX ст.: соціально-політичний портрет. Київ : Либідь, 1993. 72 с.

15. Киреева У. Т. Профессионально-педагогическая подготовка учителя начальной школы России второй половины XIX - начала XX вв. : Дис. ... 
канд. пед. наук: 13.00.01 / Московский госпединститут. Москва, 1990. 216 c.

16. Козій М. К. Розвиток середньої педагогічної освіти в Україні (1945-1990 рр.) : Дис. ... канд. пед. наук: 13.00.01 / Ін-т педагогіки АПН України. Київ, 1994. 174 с.

17. Корж Л.В. Освітня діяльність земств Харківщини (в кінці XIX на початку XX ст.): Дис. ... канд. пед. наук: 13.00.01 / Сумський держуніверситет. Суми, 1999. 190 с.

18. Кравченко I. М. Підготовка вчителя початкової школи в Києві на початку ХХ ст.: досвід діяльності Київського вчительського інституту. Вересень. 2007. № 3-4 (40-41). С. 153-162.

19. Кравченко I. М. Професійно-педагогічна підготовка в учительських інститутах України другої половини XIX - початку XX ст. Вісник Національного технічного університету України «Київський політехнічний інститут». Серія «Філософія, психологія, педагогіка». Київ, 2005. № 3 (15). С. 57-62.

20. Кравченко I. М. Учительські інститути в системі підготовки педагогічних кадрів в Україні (друга половина XIX - початок XX ст.) : Дис. ... канд. пед. наук: 13.00.01 / Національний педуніверситет ім. М. П. Драгоманова. Київ, 2008. 178 с.

21. Кравченко I. М. Феодосійський учительський інститут - центр навчальновиховного комплексу (друга половина XIX - початок XX ст.). Історикопедагогічні студї: науковий часопис. Київ, 2007. Вип. 1. С. 46-51.

22. Кравченко I. М. Феодосійський учительський інститут як основа формування мережі вчительських інститутів України другої половини XIX початку ХХ ст. Проблеми сучасної педагогічної освіти: зб. статей. Ялта, 2006. Вип. 10, ч. 1. С. 252-257.

23. Курченко В. В.Діяльність земств України у розвитку освіти (18641914 рр.) : Дис. ... канд. іст. наук: 07.00.01 / Харківський держуніверситет ім. В. Каразіна. Харків, 1997. 183 с.

24. Латышина Д. И. История педагогики: воспитание и образование (X нач. ХХ вв.) : Уч. пособие. Москва : Гардарики, 2006. 603 с.

25. Левицька Н. М. Студенство України на зламі ХІХ-XX ст. Icmopiя України. 1998. № 17. С. 23-34; № 19. С. 45-56.

26. Лук'янченко О. М. Організація педагогічної практики в різних типах педагогічних навчальних закладів України (друга половина XIX початок XX ст.) : Дис. ... канд. пед. наук: 13.00.01 / Харківський національний педуніверситет ім. Г. С. Сковороди. Харків, 2004. 170 с.

27. Луценко Е. М. Развитие среднего специального образования на Украине во второй половине XIX ст. : Дис. ... канд. ист. наук: 07.00 .02 / КНУ ім. Т. Шевченко. Киев, 1991. 169 с.

28. Майборода В. К. Вища педагогічна освіта в Україні: історія, досвід, уроки (1917-1985 рр.). Київ : Либідь, 1992. 196 с. 
29. Надольська Ю. А. Тенденції розвитку освіти і педагогічної думки Півдня України (друга половина XIX - початок XX століття) : Дис. ... канд. пед. наук: 13.00.01 / Київський національний педуніверситет. Київ, 2012. 262 с.

30. Пилипчук О. Я., Коновець О. Ф., Яресько Л. П. Історія науки та освіти в Україні. Київ : Міжнародна фінансова агенція, 1998. 79 с.

31. Пометун О. І. Навчання дітей вітчизняної історії в українській початковій школі кінця XIX - початку XX ст. Педагогіка і психологія. 1996. № 2 (11). C. $152-159$.

32. Попова О. В. Розвиток інноваційних процесів у середніх загальноосвітніх навчально-виховних закладах України в XX ст. : Дис. ... д-ра пед. наук: 13.00.01 / Харківський держпедуніверситет імені Г. Сковороди. Харків, $2001.468 \mathrm{c}$.

33. Розвиток народної освіти і педагогічної думки на Україні: Нариси (X початок XX ст.) / Гончаренко С. У. та ін. За ред. М. Д. Ярмаченка. Київ : Рідна школа, 1991. 384 с.

34. Розвиток народної освіти і педагогічної думки на Харківщині / В. І. Лозова та ін; за ред. І. Ф. Прокопенка. Харків : Міська тип. № 16, 1992. 335 с.

35. Рудницька Н. В. До історії Житомирського єврейського вчительського інституту (1873-1885 рр.). Історія Украӥни. 2001. № 37. С. 8-10.

36. Рябовол Л. Т. Розвиток земської освіти в Херсонській губернії (друга половина XIX - початок XX ст.) : Автореф. дис. ... канд. пед. наук: 13.00 .01 / Криворізький держпедінститут. Кривий Ріг, 2001. 20 с.

37. Сучков И. В. Учительство России в конце XIX - начале XX вв. : Дис.... д-ра ист. наук: 13.00.01; 07.00.02 / Московский госпединститут. Москва, 1995. $548 \mathrm{c}$.

38. Хомич Л. О. Професійно-педагогічна підготовка вчителя початкових класів. Київ : Магістер-S, 1998. 200 с.

39. Шип Н. А. Интеллигенция на Украине (XX ст.): историко-социальный очерк. Киев : Наукова думка, 1991. 170 с.

\section{References}

1. Alyeksyeyev, Yu. M. (1998). Ukrayina: osvita i derzhava (1987-1997) [Ukraine: Education and the State (1987-1997)]. Kyiv : Ekspres-ob"yava.

2. Byelashov, V. I., Hurets', M. P., Zaika, V. V. (1994). Hlukhivs'kyy derzhavnyy pedahohichnyy instytut (1874-1994 rr.) [Glukhiv State Pedagogical Institute (1874-1994)]. Sumy : Mriya.

3. Vykhrushch, V. O. (2001). Rozvytok teoretyko-kontseptual'nykh osnov vitchyznyanoyi dydaktyky (druha polovyna XIX - pochatok XX st.) [Development of theoretical and conceptual foundations of the national didactics (the second half of the XIX and early XX centuries)] : Avtoref. dys. ... d-ra ped. nauk: 13.00.01 / Nats. ped. un-t. Kyiv.

4. Havrysh, R. L., Loburets', V. S. (1997). Pidhotovka vchytel's'kykh kadriv v Ukrayini doradyans'koyi doby [Training of teaching staff in Ukraine before the 
Soviet era]. Naukovi zapysky psykhol.-ped. f-tu Poltavs'koho pedinstytutu. Poltava, 1, S. 47-52.

5. Havrysh, R. L. (1998). Shkil'na diyal'nist' zems'koho samovryaduvannya na Livoberezhniy Ukrayini v 1865-1919 rr. [School activity of the Zemstvo selfgovernment in Livoberezhna Ukraine in 1865-1919] : Dys. ... kand. ist. nauk: 07.00.01 / Poltavs'kyy pedinstytut. Poltava.

6. Hupan, N. M. (2002). Ukrayins'ka istoriohrafiya istoriyi pedahohiky [Ukrainian historiography of the history of pedagogy]. Kyiv : «A. P. N.».

7. Dem'yanenko, N. M., Vazhins'kiy, I. P. (2002). Retrospektyva pedahohichnoyi osvity v Ukrayini (XIX - pochatok XX st.) [Retrospective of pedagogical education in Ukraine (XIX - early XX century)]. Moskva : MPA.

8. Dem'yanenko, N. M. (1998). Zahal'nopedahohichna pidhotovka vchytelya $\mathrm{v}$ Ukrayini (XIX - persha tretyna XX st.) [General pedagogical teacher training in Ukraine (XIX - first third of XX century)]. Kyiv : IZMN.

9. Yevdokimov, V. I., Yel'nikova, H. V., Kornilov, V. V. (1992). Rozvytok narodnoyi osvity y pedahohichnoyi dumky na Kharkivshchini [Development of public education and pedagogical thought in the Kharkiv region]. Kharkiv: KHDPI.

10. Zadorozhna, L. V. (2000). Ideyi pedahohichnoyi maysternosti v diyal'nosti Hlukhivs'koho vchytel's'koho instytutu (1874-1917 rr.) [Ideas of pedagogical skill in the activity of the Glukhiv Teacher's Institute (1874-1917)] : Dys. ... kand. ped. nauk: 13.00.01 / Luhans'kyy derzhavnyy peduniversytet im. T. Shevchenko. Luhans'k.

11. Zadorozhna, L. V. (1999). Pedahohichni zdobutky vykladachiv Hlukhivs'koho uchytel's'koho instytutu dorevolyutsiynoho periodu 1874-1917 rr. [Pedagogical achievements of teachers of the Hlukhiv Teachers' Institute of the pre-revolutionary period of 1874-1917]. Navchal'nyy posibnyk. Hlukhiv : RVV HDPI.

12. Zolotukhina, S. T. (1997). Pidhotovka maybutnikh uchyteliv do naukovodoslidnoyi ta metodychnoyi roboty [Preparation of future teachers for research and methodological work]. Zasoby navchal'noyi ta naukovometodychnoyi roboty. Kharkiv, 2, 38-42.

13. Istoriya pedagogiki i obrazovaniya [History of Pedagogy and Education]. Uch. posob. dlya ped. ucheb. zved. / Pod red. A. I. Piskunova (2001). Moskva : Sfera.

14. Kas'yanov, H. V. (1993). Ukrayins'ka intelihentsiya na rubezhi XIX-XX st.: sotsial'no-politychnyy portret. [Ukrainian intelligentsia at the turn of the XIX and XX centuries: socio-political portrait]. Kyiv : Lybid'.

15. Kireyeva, U. T. (1990). Professional'no-pedagogicheskaya podgotovka uchitelya nachal'noy shkoly Rossii vtoroy poloviny XIX - nachala XX vv. [Professional-pedagogical preparation of the teacher of the primary school of Russia in the second half of the XIX and early XX centuries] : Dis. ... kand. ped. nauk: 13.00.01 / Moskovskiy gospedinstitut. Moskva. 
16. Koziy, M. K. (1994). Rozvytok seredn'oyi pedahohichnoyi osvity v Ukrayini (1945-1990 rr.) [Development of secondary pedagogical education in Ukraine (1945-1990)] : Dys. ... kand. ped. nauk: 13.00.01 / In-t pedahohiky APN Ukrayiny. Kyiv.

17. Korzh, L. V. (1999). Osvitnya diyal'nist' zemstv Kharkivshchyny (v kintsi $\mathrm{XIX}$ - na pochatku XX st.) [Educational activity of Kharkiv zemstvos (at the end of the XIX and early XX centuries)] : Dys. ... kand. ped. nauk: 13.00.01 / Sums'kyy derzhuniversytet. Sumy.

18. Kravchenko, I. M. (2007). Pidhotovka vchytelya pochatkovoyi shkoly v Kyyevi na pochatku XX st.: dosvid diyal'nosti Kyyivs'koho vchytel's'koho instytutu [Preparation of an elementary school teacher in Kyiv at the beginning of the XX century: experience of the Kiev Teachers' Institute]. Veresen', 3-4 (40-41), 153-162.

19. Kravchenko, I. M. (2005). Profesiyno-pedahohichna pidhotovka v uchytel's'kykh instytutakh Ukrayiny druhoyi polovyny XIX - pochatku XX st. [Vocational-pedagogical preparation in the teachers' institutes of Ukraine of the second half of the XIX and early XX centuries]. Visnyk Natsional'noho tekhnichnoho universytetu Ukrayiny «Kyyivs'kyy politekhnichnyy instytut». Seriya «Filosofiya, psykholohiya, pedahohika». Kyiv, 3, 57-62.

20. Kravchenko, I. M. (2008). Uchytel's'ki instytuty v systemi pidhotovky pedahohichnykh kadriv v Ukrayini (druha polovyna XIX - pochatok XX st.) [Teachers' Institutions in the Teacher Training System in Ukraine (the second half of the XIX and early XX centuries)] : Dys. ... kand. ped. nauk: 13.00.01 / Natsional'nyy peduniversytet im. M. P. Drahomanova. Kyiv.

21. Kravchenko, I. M. (2007). Feodosiys'kyy uchytel's'kyy instytut - tsentr navchal'no-vykhovnoho kompleksu (druha polovyna XIX - pochatok XX st.) [Feodosia Teachers' Institute - the center of the educational complex (second half of the XIX - early XX century)]. Istoryko-pedahohichni studiyi: naukovyy chasopys. Kyiv, 1, 46-51.

22. Kravchenko, I. M. (2006). Feodosiys'kyy uchytel's'kyy instytut yak osnova formuvannya merezhi vchytel's'kykh instytutiv Ukrayiny druhoyi polovyny XIX - pochatku XX st. [Feodosia Teachers 'Institute as the basis for the formation of a network of Ukrainian Teachers' Institutes of the second half of the XIX and early XX centuries]. Problemy suchasnoyi pedahohichnoyi osvity: zb. statey. Yalta, 10 (1), 252-257.

23. Kurchenko, V. V. (1997). Diyal'nist' zemstv Ukrayiny u rozvytku osvity (1864-1914 rr.) [Activities of Ukrainian zemstvos in the development of education (1864-1914)] : Dys. ... kand. ist. nauk: 07.00.01 / Kharkivs'kyy derzhuniversytet im. V. Karazina. Kharkiv.

24. Latyshina, D. I. (2006). Istoriya pedagogiki: vospitaniye i obrazovaniye (X nach. XX vv.) [History of Pedagogy: Education and Education (X-early XX centuries)] : Uch. posobiye. Moskva : Gardariki. 
25. Levyts'ka, N. M. (1998). Studenstvo Ukrayiny na zlami XIX-XX st. [Student of Ukraine at the turn of the XIX and XX centuries]. Istoriya Ukrayiny, 17, 23-34; 19, 45-56.

26. Luk"yanchenko, O. M. Orhanizatsiya pedahohichnoyi praktyky v riznykh typakh pedahohichnykh navchal'nykh zakladiv Ukrayiny (druha polovyna XIX - pochatok XX st.) [Organization of pedagogical practice in different types of pedagogical educational institutions of Ukraine (second half of the XIX and early XX centuries)]: Dys. ... kand. ped. nauk: 13.00.01 / Kharkivs'kyy natsional'nyy peduniversytet im. H. S. Skovorody. Kharkiv.

27. Lutsenko, Ye. M. (1991). Razvitiye srednego spetsial'nogo obrazovaniya na Ukraine vo vtoroy polovine XIX st. [The development of secondary specialized education in Ukraine in the second half of the XIX century] : Dis. ... kand. ist. nauk: 07.00.02 / KNU ím. T. Shevchenko. Kyiv.

28. Mayboroda, V. K.(1992). Vyshcha pedahohichna osvita v Ukrayini: istoriya, dosvid, uroky (1917-1985 rr.) [Higher pedagogical education in Ukraine: history, experience, lessons (1917-1985)]. Kyiv : Lybid'.

29. Nadol's'ka, Yu. A. (2012). Tendentsiyi rozvytku osvity i pedahohichnoyi dumky Pivdnya Ukrayiny (druha polovyna XIX - pochatok XX stolittya) [Trends in the Development of Education and Pedagogical Thought in the South of Ukraine (the second half of the XIX and early XX centuries)] : Dys. ... kand. ped. nauk: 13.00.01 / Kyyivs'kyy natsional'nyy peduniversytet. Kyiv.

30. Pylypchuk, O. Ya., Konovets', O. F., Yares'ko, L. P. (1998). Istoriya nauky ta osvity $\mathrm{v}$ Ukrayini [History of science and education in Ukraine]. Kyiv: Mizhnarodna finansova ahentsiya.

31. Pometun, O. I. (1996). Navchannya ditey vitchyznyanoyi istoriyi v ukrayins'kiy pochatkoviy shkoli kintsya XIX - pochatku XX st. [Teaching of children of national history in the Ukrainian elementary school of the end of $X I X$ - beginning of the XX century]. Pedahohika i psykholohiya, 2(11), S. $152-159$.

32. Popova, O. V. Rozvytok innovatsiynykh protsesiv u serednikh zahal'noosvitnikh navchal'no-vykhovnykh zakladakh Ukrayiny $\mathrm{v}$ XX st. [Development of innovative processes in secondary general educational institutions of Ukraine in the XX century]: Dys. ... d-ra ped. nauk: 13.00.01 / Kharkivs'kyy derzhpeduniversytet imeni H. Skovorody. Kharkiv.

33. Rozvytok narodnoyi osvity i pedahohichnoyi dumky na Ukrayini: Narysy (X pochatok XX st.) [Development of public education and pedagogical thought in Ukraine: Essays (X-the beginning of the XX century)] / Honcharenko S. U. ta in. Za red. M. D. Yarmachenka. (1991). Kyiv : Ridna shkola.

34. Rozvytok narodnoyi osvity i pedahohichnoyi dumky na Kharkivshchyni [Development of public education and pedagogical thought in the Kharkiv region] / Lozova V. I. ta in. Za red. I. F. Prokopenka. (1992). Kharkiv : Mis'ka typ. № 16. 
35. Rudnyts'ka, N. V. (2001). Do istoriyi Zhytomyrs'koho yevreys'koho vchytel's'koho instytutu (1873-1885 rr.) [To the history of Zhytomyr Jewish Teachers' Institute (1873-1885)]. Istoriya Ukrayiny, 37, 8-10.

36. Ryabovol, L. T. (2001). Rozvytok zems'koyi osvity v Khersons'kiy huberniyi (druha polovyna XIX - pochatok XX st.) [Development of rural education in the Kherson province (second half of the XIX - early XX centuries)] : Avtoref. dys. ... kand. ped. nauk: 13.00.01 / Kryvoriz'kyy derzhpedinstytut. Kryvyy Rih.

37. Suchkov, I. V. (1995). Uchitel'stvo Rossii v kontse XIX - nachale XX vv. [The teaching of Russia in the late XIX and early XX centuries] : Dis. ... d-ra ist. nauk: 13.00.01; 07.00.02 / Moskovskiy gospedinstitut. Moskva.

38. Khomych, L. O. (1998). Profesiyno-pedahohichna pidhotovka vchytelya pochatkovykh klasiv [Vocational-pedagogical preparation of elementary school teachers]. Kyiv : Mahister-S, 1998.

39. Ship, N. A. (1991). Intelligentsiya na Ukraine (XX st.): istoriko-sotsial'nyy ocherk [Intellectuals in Ukraine (XX century): a historical and social essay]. Kiyev : Naukova dumka.

УДК [94(477):338.22] «1900/1914»

\section{ПРИБАЛТІЙСЬКИЙ ПАЛИВНИЙ РИНОК: СПРОБИ ЙОГО ЗАВОЮВАННЯ ДОНЕЦЬКИМ ВУГІЛЛЯМ НА ПОЧАТКУ ХХ ст.}

\section{Шандра Ірина}

У статті досліджується спроба завоювання прибалтійського паливного ринку донецьким вугіллям на початку XX cm., проаналізовано головні напрями доставки кам'яного вугілля з Донбасу до прибалтійських споживачів (залізничне сполучення, морські перевезення довкола Європи, Дніпровсько-Двінський водний канал). Дослідження базується на загальнонаукових $і$ спеціально-історичних методах (статистичний, порівняльноісторичний, ретроспективний тощсо); в його основу покладено міждисииплінарний і корпоративістський підходи.

На основі діловодної документаиії представницьких організацій підприємиів, матеріалів періодичних видань, урядових розпоряджень у статті показано, що добувна спроможність донецької кам'яновугільної промисловості на початку XX $\mathrm{cm}$. значно переважала наявний попит. Охарактеризовано особливості прибалтійського паливного ринку (залежність від англійського палива, взаємопов'язаність вугільного імпорту та хлібного експорту в Північно-Західному краї). Простежено еволюиію поглядів державних діячів щңодо заміни донецьким вугіллям англійського 